human intellect; formulating the problem often generates solutions.

Democracy needs some people to shout loudly about the problems of the world in which we live, but such claims must be treated critically. That is Lomborg's thesis. Pimm and Harvey tell us that the main extinction threat is to species nothing is known about, which suggests these claims are hand-waving exercises. If nothing is known, how can extinction - or even teetering on the brink be predicted?

If wilderness and species are to be saved from extinction, farming should be as efficient as possible. Excess agricultural land can then be returned to its original condition. Conservation is important, of course, but Pimm and Harvey's review suggests a common confusion with preservation. Human survival is the priority. Like all species in large numbers, our presence drives others to extinction. But new species will evolve to take advantage of the new environments created.

Open democratic debate about conservation policy is essential because there are many calls on public resources. The policies that are decided have to be the best return for money, and the public should vote on the outcome. In listing with glee the industry that will attempt to rubbish, instead of debate, Lomborg's book, Pimm and Harvey may have shot themselves in their feet. Such vehemence invites the conclusion that Lomborg (and Simon) have indeed exposed basic flaws in green political dogma.

Anthony Trewavas

Institute of Cell and Molecular Biology, Mayfield Road, University of Edinburgh, Edinburgh EH9 3JH, Scotland

\section{Belief in our dominion is a backward step}

Sir - It is disheartening to read your News item "Vatican approves use of animal transplants 'to benefit humans"' (Nature 413, 445; 2001). It is the rationale of the Pontifical Academy, rather than its approval of xenotransplantation, that is particularly worrisome.

According to your report, "the academy argues that because humans enjoy a unique and superior dignity, and God has placed non-human creatures at the service of people, the sacrifice of animals is justified as long as there will be a 'relevant benefit for humans."'

This smacks of a return to predarwinian human arrogance and egotism. Didn't humanity long ago abdicate its monarchy over creation, giving up at last the notion of 'special creation' and human 'dominion over all things'? Even in the thirteenth century, St Francis of Assisi preached that all of nature, having been created by God, is important and worthy of respect.

I can think of few more dangerous attitudes than that promulgated in Genesis 1:28 and now by the Vatican, exhorting humanity, as the crown of creation, to "have dominion ... over every living thing". At what cost, mastery?

\section{Robert C. Fleck}

Physical Sciences Department, Embry-Riddle Aeronautical University, 600 S. Clyde Morris Blvd, Daytona Beach, Florida 32114, USA

\section{It's Sulston all right - but not as we know him}

Sir-Martin Kemp, in his "Science in Culture” article on Mark Quinn's A Genomic Portrait: Sir John Sulston points out that rather than a portrait, the artist has generated something akin to a relic (Nature 413, 778; 2001).

In the artist's production of an artefact which may not be art, there is more than a hint of a parallel with Sulston's achievement. Here the scientist (and the Human Genome Project) has generated something which is not science, but a remarkable triumph of technology and organization - a catalogue of the human genome sequence. The interpretation of this triumph awaits the ingenuity of contemporary and future scientists.

Quinn has enlisted collaborators too; several million bacteria, some of which have been persuaded to take up fragments of Sulston's DNA. Like most representations, aspects of the subject will be missing from the finished work unclonable portions of DNA which have not inserted into the bacteria. Artists consciously or unconsciously choose to emphasize certain features and downplay or omit others. In Quinn's case, he cannot direct the omission and lacks the means to decode the image for the observer.

Jerry Lanchbury

Molecular Immunogenetics Unit, Department of Rheumatology, Division of Medicine, GKT School of Medicine, King's College, London SE1 9RT, UK

\section{Reality hits postdocs earlier in France}

Sir - Your News story "Young, gifted ... and spurned" on the French postdoctoral system (Nature 414, 145; 2001) portrays a one-sided view of the French system. Although your report makes some valid points, it fails to acknowledge that the UK and US systems have many disadvantages, in the light of which it is not clear that the French system is worse.

In France, scientists gain tenure much earlier than their counterparts in Britain and the United States, which means that the former have more time and opportunity to formulate long-term research plans. Not every piece of research can generate several papers a year. Many topics, such as child development or ecology, need to be followed for years before a conclusion can be reached.

British and US postdocs generally waste a lot of potential research time writing proposals for renewal of short-term contracts. In the French system, postdocs are civil servants, so are less susceptible to having their research directed and can more easily conduct 'unfashionable' research without fear of losing next year's support.

The temporary contracts used in the UK and US systems mean that people can be forced to do 'trendy' research, or the research that one's professor or head of department wants done, to safeguard funding. This is not conducive to originality - it takes time to tell whether a piece of research is of fundamental importance. Bibliometric measures only tell us which topics are popular, but we could all be wrong, as history has often shown.

The deluge of postdoctoral workers in British and US universities stems from the often indiscriminate recruitment of $\mathrm{PhD}$ students essentially to do technicians' work but more cheaply and more disposably. Hence, after obtaining a $\mathrm{PhD}$ and holding a postdoctoral post or two, it becomes difficult to continue, because a disproportionately large number of qualified candidates are chasing a smaller number of vacancies. In France, it is difficult to find a job immediately after obtaining a $\mathrm{PhD}$. So the difference between the two systems is that reality hits the researcher earlier in France.

There are more postdocs for each tenured post in the British system than in the French system. Even if there were not, it could be argued that the French system is fairer, as researchers know early on in their career if they can continue in scientific research, and are likely to be able to change careers more effectively than they can when they are older.

P.-L. Chau

Department of Biochemistry, University of Cambridge, Cambridge CB2 1QW, UK

\section{correspondence}

contributions to correspondence may be submitted to corres@nature.com. They should be no longer than 500 words, ideally shorter. Published contributions are edited for length. 